\title{
I. ARTYKUŁY
}

\author{
RomAn BUDZINOWSKI
}

ORCID: 0000-0003-4218-3143

\section{The science of agricultural law in Poland. Reflections against the background of Western European science}

1. The fifteenth anniversary of Poland's accession to the European Union (EU) and inclusion of Polish agriculture within the mechanisms of the Common Agricultural Policy (CAP) ${ }^{1}$ prompts one to make summaries and comparisons and formulate evaluations concerning various areas of economy and law, including agriculture and agricultural law. Economists, for example, study the impact of EU funds on the development of Polish agriculture, how they increased farmers' incomes or contributed to the changes in infrastructure. ${ }^{2}$ Agricultural lawyers, on the other hand, quite understandably highlight the role of EU agricultural law as this law has dominated legal regulation of this branch of the economy. The number of legal norms governing various aspects of agriculture has increased and the scope of agricultural law regulations has been extended. European Union membership has brought about the biggest leap forward in agricultural legislation in the history of agriculture so far. Many issues have been regulated for the first time, while domestic law

${ }^{1}$ Poland joined the European Union on 1 May 2004.

${ }^{2}$ See e.g. C. Klimkowski (ed.), Ocena wybranych elementów unijnej polityki rolnej, Warszawa 2015; W. Poczta, J. Rowiński (eds.), Struktura polskiego rolnictwa na tle Unii Europejskiej, Warszawa 2019. 
Poland's EU membership induced a return of a special regulation of trading in agricultural property. ${ }^{3}$

Therefore it may be said that the inclusion of Polish agriculture in the CAP mechanisms has significantly strengthened the legislative status of this area of legislation; the expansion of agricultural law has opened up a huge research space, while the integration within the EU has created a common for all Member States platform for undertaking research on the legal regulation of agriculture.

As a result, the problems of agricultural law in Poland and other EU member states are, if not the same, identical. On the other hand, already years ago A. Carrozza ${ }^{4}$ wrote that the characteristics of agriculture and agricultural production itself encourage the unification of legislation, and so does the international factor, too. It should be noted that in Poland, especially before the change of the social and economic system in 1989, agricultural law reflected the system of planned economy and was strongly determined by political considerations. Therefore, and not surprisingly, more attention in the literature was then paid to the distinctiveness of the Polish regulation. However, already in the 1980s a strong emphasis was placed on comparative legal research and drawing on the achievements of Western European legislation and science. ${ }^{5}$

The inclusion of Polish agriculture in the CAP mechanisms became an impulse for the intensification of research activity and opened a new stage of the development of the science of agricultural law. It is obvious that the position of this science, both in Poland and in the EU member states, is determined by the development of not only national (local) and EU (regional) legislation and international agricultural law, but also by the intensity of research and the development of the scientific community. Every legislator must take into account the challenges of today's world, such as food security, food safety, environmental and climate protection, conservation of land and water resources, etc. These challenges combine the global, regional and local aspects of agricultural

${ }^{3}$ The Act of 11 April 2003 on shaping the agricultural system (Journal of Laws No 64, item 592) as amended.

${ }^{4}$ See A. Carrozza, Les sources "lointaines" du droit rural et leur action sur la scène mondiale, in his collected works: Scritti di diritto agrario, Milano 2001, p. 904 et seq.

${ }^{5}$ A. Lichorowicz, who in the mid-eighties of the last century justified the relevance and importance of comparisons between the legal solutions of countries with different regimes, has particular merits in conducting and disseminating comparative legal research in agricultural law - see: Dzierżawa gruntów rolnych $w$ ustawodawstwie krajów zachodnioeuropejskich, Kraków 1986, and later monographs: Szczególne zasady dziedziczenia gospodarstw rolnych w ustawodawstwie zachodnioeuropejskim, Kraków 1992; Status prawny gospodarstw rodzinnych w ustawodawstwie krajów Europy Zachodniej, Białystok 2000. 
policy and agricultural law. ${ }^{6}$ They determine the research field for the science of this law, which can no longer be closed solely in the circle of local issues, ${ }^{7}$ and strengthen the need to carry out such research.

The fifteenth anniversary of the inclusion of Polish agriculture in the CAP mechanisms calls for summarising and assessing the development of the science of agricultural law in the European context. Eight years ago, a statement was formulated in the literature that the development of Polish science of agricultural law was lagging behind Western European science, especially in the area of research related to agricultural policy and EU agricultural law. ${ }^{8}$ It seems that today the situation is quite different. This article will demonstrate that this distance before the state of affairs in Poland and Western Europe has been significantly reduced, and that Polish agricultural lawyers are increasingly becoming partners in research carried out by foreign researchers, while their research results and organisational capabilities may be successfully used on the international forum.

Although the deliberations in this article concern the science of agricultural law, they should not be dissociated from the development of legislation. The vast scope of the subject matter of research enforces a more synthetic course of narration and the reference to legislative acts and bibliographical items only for the sake of an example. For this reason it is also impossible to enumerate, and the more so discuss in greater detail, all the issues raised in the literature. Thus only the subject matter of selected new directions of development of the science of agricultural law in Poland will be outlined here, in order to compare them with the achievements of this science in Western European countries.

Therefore, this article is only an attempt to formulate a few valid reflections, focusing on the comparison of the EU agricultural acquis, the general (theoretical) agricultural (national) law issues, traditional agricultural law issues, agri-food and agri-environmental law and rural development. It is also necessary to characterise and assess the internationalisation of research related to this activity, i.e. the activity carried out in international scientific organisations, the organisation of international congresses and conferences, presentation of papers at scientific meetings, foreign scientific internships, lectures delivered and publications published abroad, and the like.

${ }^{6}$ For more see: R. Budzinowski, Contemporary challenges of Agricultural Law: among Globalisation, Regionalisation and Locality, in: R. Budzinowski (ed.), XV World Congress of Agricultural Law. Contemporary challenges of Agricultural Law: among Globalisation, Regionalisation and Locality, Poznań 2018, p. 16 et seq.

${ }^{7}$ Ibidem, p. 23.

${ }^{8}$ R. Budzinowski, O potrzebie rozwoju nauki prawa rolnego, "Przegląd Prawa Rolnego" 2012, No 1, p. 22. 
Obviously, the inclusion - for the purpose of comparison - of the agricultural law acquis of the EU Member States will not be uniformly taken into account; in particular, the reference point for evaluations will be the acquis of Italian, German, Spanish and, to a lesser extent, French science, i.e. that of the countries with which Polish academics cooperate more closely. ${ }^{9}$

2. Although these considerations cover the period of the last fifteen years, it is worthwhile to draw some observations, even of a sketchy nature, about the development of the science of agriculture in the past and the development of the scientific staff specialising in this particular discipline of knowledge. In Poland, the science of agricultural law commenced in the inter-war period of the last century (1919-1939 ${ }^{10}$ and has developed gradually, passing through a number of political changes, always being close to politics.

During the first twenty years of the Polish People's Republic (after 1944), the main subject of research was primarily the restructuring of the agricultural system (agricultural reform, settlement and enfranchisement).

A significant increase in research intensity took place in the subsequent 1960s and 1970s. This was connected with the extension of the scope of agricultural regulation (e.g. cooperation, specialisation, teams of individual farmers, or individual farmers' insurance). A discussion on general (theoretical) problems of agricultural law was initiated, and it included the definition of agricultural law, its subject matter, and its separation in the Polish system of law. ${ }^{11}$

In the 1970s, agricultural law became a distinct and mandatory subject in the curriculum of legal and administrative studies. Almost all university centres created separate departments of agricultural law.

The social and economic transformation of 1989 resulted in a certain weakening of the status of agricultural law as a scientific discipline. The transformation period saw a significant reduction of agricultural legislation as a consequence of the implementation of market economy. Research activity was temporarily restricted, partially due to the change of generations, the more active involvement of some senior researchers in public affairs reduced levels of staff in the agricultural departments, and even liquidations of the latter in some

${ }^{9}$ In addition to monographic studies, publications published in the following journals will be a reference point for consideration: "Agrar- und Umweltrecht," "Revista de Derecho Agrario y Alimentario," "Revue de Droit Rural," "Rivista di Diritto Agrario," "Rivista Agroalimentare, "Studia Iuridica Agraria" and "Przegląd Prawa Rolnego."

${ }^{10}$ For more on the genesis of agricultural law in Poland against the European background see: R. Budzinowski, La génesis del derecho agrario en Polonia desde la perspectiva de la experiencia europea, "Revista de Derecho Agrario y Alimentario" 2017, No 2, p. 29 et seq.

${ }^{11}$ See J. Paliwoda (ed.), Zagadnienia prawne rolnictwa, Wrocław 1970 (particularly the article by A. Stelmachowski, Prawo rolne w systemie polskiego prawa, p. 5 et seq.). 
university centres. However, despite these difficulties, the following 1990s and the first years of the new century saw an increase in research intensity. Moreover, new issues were given attention as well, among them those related to the changes in the political system in agriculture or to the adaptation of national law to the requirements of EU law.

This increase in research intensity was also possible due to the increasing numbers of faculty members, specialising in agricultural law. In the first years of Poland's membership in the EU, the number of titular agricultural law professors increased, as did the number of associate professors known as "habilitated doctors." Moreover, the youngest generation of agricultural lawyers also came to the fore. Their academic careers started only in recent years and some of them work as doctors of legal sciences, while others have already achieved the status of an independent scientific-research worker (following the "habilitation" procedure). This reinforcement of the agricultural law science, although not yet common in all university centres, constituted a good basis for intensive research in the first years of EU membership.

3. The issues of the common agricultural policy and EU (formerly: Community) agricultural law were the subject of research long before Poland joined the European Union. The earliest to undertake them were economists, ${ }^{12}$ followed by agricultural lawyers who became especially active after the signature on 16 December 1991 of the Agreement establishing an association between the Republic of Poland and the European Communities and their Member States. ${ }^{13}$ This Agreement imposed an obligation to implement adjustment measures to approximate Polish legal regulations to the provisions of Community law. For this reason, already at the initial stage of the association period, priorities were identified and the scope of necessary adjustment measures in agricultural law determined. ${ }^{14}$

A number of materials were also published, in the form of monographs or numerous articles, which introduced the Polish reader to selected issues of the CAP and Community agricultural law. ${ }^{15}$ They also contained indications as to

${ }_{12}$ For example M. Ciepielewska, Wspólna polityka rolna EWG, Warszawa 1981.

13 The Agreement came into force on 1 February 1994.

${ }^{14}$ See, in particular A. Lichorowicz: Il problema dell'armonizzazione della legislazione agraria polacca con l'ordinamento giuridico della CEE, "Rivista di Diritto Agrario" 1992, issue 3, p. 502 et seq.; idem, Stowarzyszenie Polski z EWG a polskie ustawodawstwo rolne, "Państwo i Prawo" 1992, issue 9, p. 50 et seq.; idem, Stan polskiego prawa rolnego na tle ustawodawstwa rolnego Wspólnoty Europejskiej, "Przegląd Legislacyjny" 1995, No 5, p. 12 et seq.

${ }^{15}$ Among the monographs, especially noteworthy are: A. Jurcewicz, B. Kozłowska, E. Tomkiewicz, Polityka rolna Wspólnoty Europejskiej w świetle ustawodawstwa i orzecznictwa, Warszawa 1995; A. Lichorowicz, Problematyka struktur agrarnych w ustawodawstwie Wspólnoty 
the direction of changes in the national legislation. Various aspects of the issues discussed here were also presented in the nationwide handbook on agricultural law. ${ }^{16} \mathrm{~A}$ comprehensive approach to the adjustment issues was reflected in a monograph published in 2001. ${ }^{17}$ Among experts involved in the drafting of legislative acts implementing EU regulations into the Polish legal order were agricultural lawyers. It is also worth noting that as early as in the first half of the 1990s the common agricultural policy and Community agricultural law became subjects taught as part of a law course at a number of university law faculties.

Therefore, it may be concluded that upon Poland's accession to the European Union, Polish agricultural lawyers were fairly well prepared to take up research into EU agricultural law. Initially, the research effort was focused on the implementation of EU legislative acts into Polish law, and over time, on the analysis of particular aspects or regulations implementing the CAP. ${ }^{18}$ A particular interest among researchers was always in the change of the legal basis of the CAP in the subsequent funding period, especially from the Polish perspective. ${ }^{19}$

There are countless articles on various issues pertaining to EU agricultural law, ranging from the regulation of agricultural markets, through the structural policy and rural development, to agri-food and agri-environmental law. Other subjects of interest included reflections on general issues of EU agricultural law, such as, for example, its sources, the role of case-law or its evolution, ${ }^{20}$

Europejskiej, Kraków 1996; P. Czechowski, W. Ziętara, Konkurencja a regulacja w rolnictwie, Warszawa 1995; E. Tomkiewicz, Limitowanie produkcji w ustawodawstwie rolnym Wspólnoty Europejskiej, Warszawa 2000.

${ }_{16}$ P. Czechowski, M. Korzycka-Iwanow, S. Prutis, A. Stelmachowski, Polskie prawo rolne na tle ustawodawstwa Unii Europejskiej, Warszawa 1994.

17 P. Czechowski, Proces dostosowania polskiego prawa rolnego i żywnościowego do prawa Unii Europejskiej, Warszawa 2001.

${ }^{18}$ See for example B. Jeżyńska, Proekologiczne instrumenty wsparcia zrównoważonego rozwoju obszarów wiejskich, "Studia Iuridica Agraria" 2012, vol. X, p. 251 et seq.; D. Łobos-Kotowska, Umowa przyznania pomocy z Europejskiego Funduszu Rolnego na rzecz Rozwoju Obszarów Wiejskich a inne podobne umowy, "Studia Iuridica Agraria"2012, vol. X, p. 265 et seq.

${ }^{19}$ For example: E. Tomkiewicz, Wspólna polityka rolna po reformie z 2003 r., "Studia Iuridica Agraria" 2005, vol. V, p. 211; A. Jurcewicz, E. Tomkiewicz, Wspólna polityka rolna po 2013 roku, in: J. Bieluk et al. (eds.), Z zagadnień prawa rolnego, cywilnego i samorzadu terytorialnego. Księga Jubileuszowa Profesora Stanisława Prutisa, Białystok 2012, p. 106 et seq.; R. Budzinowski, O przyszłości wspólnej polityki rolnej-uwagi z perspektywy Polski, in: ibidem, p. 51 et seq.

${ }^{20}$ See for example B. Kozłowska, Źródła wspólnotowego prawa rolnego, in: A. Jurcewicz, B. Kozłowska, E. Tomkiewicz, Polityka rolna Wspólnoty Europejskiej w świetle ustawodawstwa $i$ orzecznictwa, Warszawa 1995, p. 9 et seq.; D. Milanowska, Wybrane metody systematyzacji prawodawstwa Unii Europejskiej z uwzględnieniem aktów prawnych z zakresu prawa rolnego, 
or issues of utmost importance for the development of EU agriculture, such as those relating to the negotiations between the EU and the USA to establish a Transatlantic Trade and Investment Partnership (TTIP), which started in 2013. Consideration was also given to the negative effects of the Agreement under negotiation. ${ }^{21}$

At this point, however, for the sake of an example, it is worth pointing to a few monographs on the subject. First of all, there is a book whose main subject is the Treaty bases of EU agricultural law. The book contains, among other things, considerations on the regulation of agriculture in the Treaty ${ }^{22}$ and may therefore be compared, to a certain extent, to works of a similar kind published in other countries. ${ }^{23}$ Extremely important, from the point of the science of agricultural law, is a study on competition rules in agriculture, based on very rich foreign literature and case-law. ${ }^{24}$ That work shows the complexity of the relationship between the agricultural policy and the competition policy and expresses the need to define a proper relationship between them.

There are also monographs devoted to novelties in EU law, such as the study on the marketing of novel foods in the EU. ${ }^{25}$ The fact remains that Polish science still lacks a work that would present EU agricultural law in a synthetical form, which is an appropriate form for a work of a treatise character, ${ }^{26}$ but this shortcoming is primarily due to the need to solve current problems first. On the other hand, the didactic needs are fully met by the elaborate and updated in

"Studia Iuridica Agraria" 2013, vol. XI, p. 11 et seq.; A. Jurcewicz, Rola orzecznictwa Trybunału Sprawiedliwości w ksztaltowaniu wspólnej polityki rolnej, "Studia Iuridica Agraria" 2001, vol. II, p. 43 et seq.

${ }^{21}$ See K. Marciniuk, Problematyka rolna $w$ świetle nowej umowy handlowej UE-USA (Transatalntic Trade \& Investemnt Agreement), "Studia Iuridica Agraria" 2013, vol. XI, p. 227 et seq. Also compare P. Bonncarrére, Les conséquences du traité transatlantique pour l'agriculture, "Revue de Droit Rural" 2016, No 442, p. 10 et seq.; B. Krüsken, TTIP - Folgen für die Agrarwirtschaft?, in: I. Härtel (ed.), Wege der Ernährungswirtschaft - global, regional, europäisch, Baden-Baden 2017, p. 157 et seq.; M. Alabrese, TTIP e agroalimentare. Prime rifflessioni a margine delle proposte dell'Unione Europea nella negoziazione della Trans-atlantic Trade and Investment Partnership, "Rivista di Diritto Agrario" 2016, issue 2, p. 210 et seq.

${ }^{22}$ A. Jurcewicz, Traktatowe podstawy unijnego prawa rolnego $w$ świetle orzecznictwa. Zagadnienia wybrane, Warszawa 2012.

${ }^{23}$ Among others A. Germanò, E. Rook Basile (Manuale di diritto agrario comunitario, 3 ed., Torino 2014, p. 79 et seq.) wrote about agriculture and its regulation in the Treaty.

${ }^{24}$ P. Popardowski, Reguly konkurencji w rolnictwie w prawodawstwie Unii Europejskiej, Warszawa 2019.

${ }^{25}$ Ł.M. Sokołowski, Prawne aspekty wprowadzania nowej żywności na rynek unijny, Poznań 2017. From the Italian literature see: V. Paganizza, Bugs in Law. Insetti e regole dai campi alla tavola, Milano 2019.

${ }^{26}$ An example in the Italian literature is a book by A. Germanò, E. Rook Basile, Diritto agrario, Torino 2006. 
subsequent editions of deliberations on the common agricultural policy and EU agricultural law contained in the new nationwide handbook on agricultural law that is currently the binding and generally. ${ }^{27}$

Many other studies dealing tacking different issues from the variety of topics discussed here will be highlighted here against the background of the development of agricultural law in Poland presented here. It is obvious that Polish agricultural lawyers had to take these issues into account. After all, EU agricultural law has become an element of the Polish legal order, and its implementation required and still requires further research. The dynamics of changes in the sphere of agri-food economy and law was so intense that with time the necessity of proving that research in the field of agricultural law is necessary and useful no longer exists. ${ }^{28}$

The aforementioned increase in research intensity is reflected in numerous monographs and a very large number of papers, articles, commentaries and other studies. ${ }^{29}$ Agricultural lawyers have the opportunity to publish their works in two agricultural law journals, including "Studia Iuridica Agraria" (founded in 2001) published by the Białystok centre and "Przegląd Prawa Rolnego" ("Agricultural Law Review" - founded in 2007) published by the Poznań acaddmic centre. Numerous articles on legal and agricultural issues are published in various other legal journals, particularly, in recent years, in "Studia Iuridica Lublinensia" published by the Lublin academic centre.

On the other hand, the impact of EU agricultural law on domestic agricultural law must be noted, and the resulting from it need to "renew" the theoretical foundations of Polish agricultural law.

In the new situation, in which EU law became the driving force behind the development of Polish agricultural law, it was reasonable to pose the question of what this law has become today, ${ }^{30}$ what its subject was, or the limits or

${ }^{27}$ P. Czechowski (ed.), Prawo rolne, Warszawa 2011 (and subsequent editions). Two other textbooks may be mentioned here (A. Jurcewicz, B. Kozłowska, E. Tomkiewicz, Wspólna polityka rolna. Zagadnienia prawne, Warszawa 2007; A. Jurcewicz (ed.), Prawo rolne i polityka rolna Unii Europejskiej, Warszawa 2010), which due to the amendment to the CAP and European Union agricultural law are already of historical value.

${ }^{28}$ I pointed to the necessity of conducting such research in my article $O$ potrzebie rozwoju nauki prawa rolnego, "Przegląd Prawa Rolnego" 2012, No 1, p. 13 et seq.

${ }^{29}$ The growing achievements of the science of agricultural law are evidenced by the list of items contained in the "Polish legal-environmental bibliography" published annually in the journal "Przegląd Prawa Rolnego."

${ }^{30}$ This question was formulated in the mid sixties of the $20^{\text {th }}$ century by K. Kroeschell, Was ist Agrarrecht?, "Recht der Landwirtschaft" 1965, No 17, p. 277. Many authors from different countries have already answered this question. Due to changes in agricultural legislation, especially the extension (expansion) of its subject matter, this question is still relevant. 
relations of agricultural law when it comes to other fields of law. The answer to this question was not only of an academic nature, but also served practical purposes, facilitating the process of law-making and law application. Thanks to this, it was possible to organise in an orderly manner numerous regulations on agriculture, differentiated according to the date of their adoption, their sources or terminology. It is particularly noteworthy to mention a monograph on general issues of agricultural law, in which factors and trends in the development of this law and its place in the legal system were analysed against the background of the many diverse doctrinal concepts. ${ }^{31}$

This research trend includes a large number of articles on various general aspects of agricultural law. It is worth noting the works that formulate the need to change the paradigm of this law, ${ }^{32}$ determine the directions of its development in the future ${ }^{33}$ as well as its approach to contemporary challenges, ${ }^{34}$ and characterise the basic concepts and constructions in terms of the European perspective. ${ }^{35}$ The considerations of the basic methodological assumptions in the science of agricultural law were to serve the purpose of organising and enriching the research workshop under new conditions, ${ }^{36}$ and indicated a desirable way in which research ought to be conducted by agricultural lawyers with a view of strengthening the status of the science of this law in the study of contemporary reality. Thus, Polish agricultural lawyers joined in the discussion on the theoretical issues of this field of law; a discussion

${ }^{31}$ R. Budzinowski, Problemy ogólne prawa rolnego. Przemiany podstaw legislacyjnych $i$ koncepcji doktrynalnych, Poznań 2008 and Western-European literature cited therein.

${ }^{32}$ For example J. Bieluk, Zmiana paradygmatu prawa rolnego, "Studia Iuridica Agraria" 2015, vol. XIII, p. 2 et seq.

${ }_{33}$ R. Budzinowski, Przyszłość prawa rolnego, "Przegląd Prawa Rolnego" 2009, No 1, p. 13 et seq; idem, Jeszcze o przyszłości prawa rolnego, "Przegląd Prawa Rolnego" 2010, No 2, p. 13 et seq. The issue of the future of agricultural law was also the subject of a Polish-Italian scholarly conference organised in Obrzycko near Poznań on 23-25 September 2010, see R. Budzinowski, Sprawozdanie, "Przegląd Prawa Rolnego" 2010, No 2, p. 259 et seq.

${ }^{34}$ R. Budzinowski, Prawo rolne wobec wspótczesnych wyzwań, "Przegląd Prawa Rolnego" 2014, No 2, p. 13; idem, Współczesne wyzwania zwiazane z żywnościa i ich rola w ksztaltowaniu polityki rolnej i prawa rolnego, "Przegląd Prawa Rolnego" 2015, № 2, p. 13 et seq.

${ }^{35}$ P. Czechowski, A. Niewiadomski, Wybrane pojęcia i konstrukcje prawa rolnego $w$ perspektywie europejskiego prawa rolnego, "Studia Iuridica Agraria" 2013, vol. XI, p. 11 et seq. Also see T. Kurowska, Miejsce i rola działalności rolniczej w prawie rolnym, "Studia Iuridica Agraria 2016, vol. XV, p. 47 et seq.

${ }^{36}$ R. Budzinowski, Podstawowe zalożenia metodologiczne w nauce prawa rolnego, "Przegląd Prawa Rolnego" 2013, No 1, p. 13 et seq.; idem in the English language: Fundamental methodological assumptions in the science of agricultural law, "CEDR Journal of Rural Law" 2015, No 1, p. 14 et seq. 
that had been going on (although with varying intensity) for a long time in Western European literature on the subject. ${ }^{37}$

The EU agricultural law has also influenced the scope and detailed subject matter of the research conducted by Polish agricultural lawyers. The science of agricultural law moved from the studies focused on the domestic law, which also accentuated the need for comparative legal research, through the crisis of the late eighties and early nineties, to addressing - already in the conditions of EU membership - issues of regional and global character. Various problems of modern agricultural law included in the scope of scientific research extended beyond traditional land issues and the organisation of agricultural production, covering also the agri-food and agri-environmental aspects and their references to the territory (rural areas). Such a broad approach to the research issues is adequate to the expansion of contemporary agricultural law which takes into account the triad: agriculture-food-environment, expressing in this way the interdependencies and directions of interaction, responding at the same time to contemporary challenges. ${ }^{38}$

Therefore, the logo of the "Przegląd Prawa Rolnego" journal, describing the thematic scope of the publication, points to agriculture, food, environment and rural areas (against the background of the rural landscape). As such, it does not differ from recognised foreign journals, which in this or similar way specify the subject of interest, and thus also indicate a wide approach to the area of research. ${ }^{39}$ For this reason, the nationwide handbook on agricultural

${ }^{37}$ See e.g. J. Foyer, Le droit rural: nouveaux horizons, "Revue de Droit Rural" 2010, No 384, pp. 1-2; A. Jannarelli, Il divenire del diritto agrario italiano ed europeo tra sviluppi tecnologici e sostenibilità, "Rivista di Diritto Agrario" 2012, issue 2, p. 11 et seq.; C. Blumann, La politique agricole commune face aux nouveaux défis planétaires et européens, "Revue de Droit Rural" 2013, No 416, p. 17 et seq.; Ch. Busse, Überlegungen zum funktionalen Agrarrechtsbegriff - Zugleich Replik auf die Erwiderung von Holzer, "Agrar- und Umweltrecht" 2014, No 4, p. 138 et seq.; idem, Sonderrechtlicher und funktionalrechtlicher Ansatz im Agrarrechtlichen Widerstreit. Ein Beitrag zur agrarrechtlichen Systembildung, Hagen 2016; L.A. Bourges, Evolutión del derecho de la agricultura: las fases históricas y la redefinición del derecho de la agricultura frente a los nuoevos desafios del siglo XXI, in: E. Muñiz Espada, P. Amat Llombart (eds.), Tratado de Derecho Agrario, Madrid 2017, chapter II; J. Martínez (ed.), Rechweite und Grenzen des Agrarrechts, Baden-Baden 2018; M. Alabrese, Agricultural Law from a Global Perspective: An Introduction, in: M. Alabrese et al. (eds.), Agricultural Law. Current Issues from a Global Perspective, Cham 2017, p. 1 et seq.

${ }^{38}$ On this regulation of agricultural matters in France see: L. Colella, La «loi agriculture et alimentation» nel modello francese: il primo passo per l'affermazione del «diritto al cibo sano e sostenibile» come valore costituzionale, "Diritto e Giurisprudenza Agraria, Alimentare e dell'Ambiente" 2016, No 6, p. 1. Also see M. Goldoni, Integrazione dell'oggetto con ambiente e alimentazione, "Diritto Agroalimentare" 2019, No 1, p. 19 et seq.

${ }^{39}$ For example, since 2005, the journal "Rivista di Diritto Agrario" has been subtitled "Agriculture. Food, Environment," the "Agrar- und Umweltrecht" refers to environmental protection 
law also presents the issues of agriculture, food law, environmental protection and support for rural development, taking into account both national, EU and international law. ${ }^{40}$

A manifestation of the impact of EU agricultural law on Polish agricultural law is the fact that now certain topics addressed within the framework of traditional agricultural law study are analysed from a slightly different perspective or completely new topic are studied. Also the issues of the agricultural real estate market have gained a much broader dimension. As it has already been mentioned, on the threshold of Poland's membership in the European Union, the Act on shaping the agricultural system was passed, and substantially amended in 2016, introducing special regulations for trading in agricultural property (agricultural holdings). ${ }^{41}$ It subsequently became the subject of numerous studies aimed at solving not only practical issues, ${ }^{42}$ but also looking at this regulation from the perspective of public authority interference in the context of the shaping of the agricultural system ${ }^{43}$ and also from the point of view of European Union law. ${ }^{44}$ On many occasions agricultural lawyers have drawn attention to the need for a modern regulation of agricultural lease, also referring to the experience of European Union Member States..$^{45}$ Innovative topics, not only at national level, should include access to agricultural land resources, including prevention of land grabbing. ${ }^{46}$

already in its title with the subtitle "common (gesamte) law on agriculture, agricultural markets and rural areas," while the "Revue de Droit Rural" has the subtitle "agriculture, agri-food (agroalimentaire), rural areas, environment."

${ }^{40}$ P. Czechowski (ed.), Prawo rolne, $5^{\text {th }}$ edition, Warszawa 2019.

${ }^{41}$ A synthetic discussion can be found in: R. Budzinowski, A. Suchoń, Purchasing and renting agricultural land in Poland: Legal Framework and pratical issues, "CEDR Journal of Rural Law" 2017, No 3, p. 94 et seq.

${ }^{42}$ For example: J. Bieluk, Ustawa o ksztaltowaniu ustroju rolnego. Commentary, $2^{\text {nd }}$ edition, Warszawa 2019.

${ }^{43}$ K. Marciniuk, Prawne instrumenty ingerencji władzy publicznej w obrót nieruchomościami rolnymi jako środki ksztattowania ustroju rolnego, Białystok 2019.

${ }^{44}$ P. Czechowski, Obrót nieruchomościami rolnymi w świetle europejskiego soft law, "Studia Iuridica Agraria 2018, vol. XVI, p. 29 et seq.; B. Jeżyńska, R. Pastuszko, Obrót nieruchomościami rolnymi a prawo Unii Europejskiej, "Problemy Rolnictwa Światowego" 2018, vol. 18, p. 156 et seq.

${ }^{45}$ For example: A. Lichorowicz, Potrzeba prawnego uregulowania dzierżawy rolnej w Polsce (na podstawie doświadczeń krajów Unii Europejskiej), "Przegląd Prawa Rolnego" 2010, № 2, p. 63 et seq.; A. Suchoń, Jeszcze o potrzebie prawnego uregulowania dzierżawy rolniczej, "Przegląd Prawa Rolnego" 2015, No 2, p. 243 et seq.

${ }^{46}$ R. Pastuszko, Land grabbing. Podstawowe zagadnienia prawne, "Studia Iuridica Lublinensia" 2017, No 1, p. 7 et seq.; idem, Dostęp do zasobów gruntów rolnych w procesach globalizacji. Zagadnienia prawne, Lublin 2019. From foreign literature see e.g. J. Martínez, Die Steuerung der Agrarstruktur durch das Grundstücksverkehrsrecht, "Agrar- und Umweltrecht" 
Much more attention has also been paid to the issues of agricultural activity, the agricultural holding and various forms of entrepreneurship in agriculture. "Agricultural activity" has become one of the basic conceptual categories of agricultural law. Particular interest was aroused by the qualification of agricultural activity as an economic activity and the definition of the status of a farmer as an entrepreneur. ${ }^{47}$ Among the agricultural holdings, a family holding which, in the light of the Constitution, is the basis of the agricultural system, has become a subject of wide interest. ${ }^{48}$ A new study, taking into account the experience of Western European countries, dealt with agricultural cooperatives. In that work, much attention was also paid to various forms of association of agricultural producers. ${ }^{49}$ Publications on the use of agricultural biomass for the purposes of energy, agri-tourism and risk management in agricultural activities could be considered innovative, too. ${ }^{50}$

It is understandable that with Poland's accession to the European Union, interest in the legal organisation of agricultural markets has increased as well. This interest has been reflected in numerous publications dealing with various aspects of this issue. Although there is no comprehensive study covering it, ${ }^{51}$ there have been a handful of studies examining certain problems in detail. In particular, for example, Polish agricultural lawyers monitored and analysed

2013, No 5, p. 165 et seq.; A.M. Cosialls Ubach, La agricultura familiar y el "land grabbing" ante la funcion social de la propiedad agraria y la nueva reforma de la PAC, "Revista de Derecho Agrario y Alimentario" 2017, No 67, p. 83 et seq.

${ }^{47}$ See e.g. B. Jeżyńska, Producent rolny jako przedsiębiorca, Lublin 2008; R. Budzinowski, $W$ kwestii statusu prawnego rolnika jako przedsiębiorcy, in: Rozprawy z prawa prywatnego. Księga pamiatkowa dedykowana Profesorowi Aleksandrowi Oleszce, Warszawa 2012, p. 47 et seq.; J. Bieluk, O potrzebie wprowadzenia do prawa polskiego pojęcia przedsiębiorstwa rolnego, "Studia Iuridica Agraria" 2013, vol. XI, p. 131 et seq.

${ }^{48}$ D. Łobos-Kotowska, Gospodarstwo rodzinne. Prawne formy organizacji, Sosnowiec 2006; T. Kurowska, Ochrona gospodarstwa rodzinnego - uwagi de lege lata i de lege ferenda, "Studia Iuridica Agraria" 2010, vol. VIII, p. 14 et seq.; S. Prutis, Status prawny rodzinnego gospodarstwa rolnego w polskim prawie rolnym (Ocena stanu regulacji), in: P. Litwiniuk (ed.), Prawne mechanizmy wspierania i ochrony rolnictwa rodzinnego w Polsce i innych państwach Unii Europejskiej, Warszawa 2015, p. 11 et seq. (and many other articles published in this collective work).

${ }^{49}$ A. Suchoń, Prawna koncepcja spótdzielni rolniczych, Poznań 2016; eadem, Zrzeszanie się producentów rolnych, in: M. Korzycka (ed.), Instytucje prawa rolnego, Warszawa 2019, p. 423 et seq.

${ }^{50} \mathrm{~K}$. Błażejewska, Prawne aspekty produkcji $i$ wykorzystania biomasy rolniczej na cele energetyczne, Poznań 2013; A. Kapała, Status prawny agroturystyki (Studium prawnoporównawcze), Poznań 2017; I. Lipińska, Prawne aspekty zarządzania ryzykiem w działalności rolniczej, Warszawa 2019.

${ }^{51}$ A synthesis of the regulation of agricultural markets in force constitutes a chapter of the nationwide handbook by P. Czechowski (ed.), Prawo rolne, p. 523 et seq. 
changes in the organisation of agricultural markets, the abolition of milk quotas, measures to protect the EU agricultural market or to safeguard competition. ${ }^{52}$ It can be said that just like Western European agricultural lawyers, they studied various aspects of the functioning of the agricultural market. ${ }^{53}$

The functioning of this market in the new conditions increased the focus of the science of agricultural law on contracts in agriculture (or more broadly - in agri-food economy). The results of studies that have been published in articles examining the traditional (in Poland) cultivation contracts that tied the agricultural producer to the entity purchasing the products contracted..$^{54}$ However, the question arose about the new functions of such contracts, as well as the possibility of using other contracts that would serve the production and supply of certain agricultural produce.$^{55}$ The 2013 CAP reform which, among other things, strengthened the importance and role of contractual relations between agricultural market participants, even encouraged scientists to study this issue more deeply. ${ }^{56}$ And yet, apart from only partial studies in selected issues, ${ }^{57}$ there has not

${ }^{52}$ See e.g. I. Lipińska, Nowe przepisy $w$ sprawie organizacji wspólnotowego rynku rolnego, "Przegląd Prawa Rolnego" 2008, No 3, p. 175 et seq.; P. Czechowski, Nowa regulacja Unii Europejskiej w zakresie wspólnej organizacji rynków rolnych, in: Obrót gospodarczy w prawie rolnym, B. Jeżyńska (ed.), Lublin 2009, p. 37 et seq.; A. Suchoń, Funkcjonowanie rynku mleka po likwidacji kwotowania - wybrane aspekty prawne, "Studia Iuridica Agraria" 2016, vol. XIV, p. 297 et seq.

${ }^{53}$ See e.g. D. Gadbin, L'«OCM unique»: le déclin de la régulation publique des marchés, "Revue de Droit Rural" 2014, No 423, p. 17 et seq.; Ch. Busse, Das Auslaufen der EU-Milchquotenregelung zum Milchquotenjahr 2014/2015, “Agrar- und Umweltrecht” 2015, No 1, p. 10 et seq.; A. Jannarelli, Agricoltura e concorrenza o concorrenza e agricoltura. Gli articoli 169, 170 e 171 del reg. 1308/2003 e il progetto guidelines presentato dalla Commissione, "Rivista di Diritto Agrario" 2015, issue 1, p. 3 et seq.

${ }^{54}$ In the cultivation contract, the producer undertakes to produce and deliver to the contracting party a specified quantity of agricultural produce of a specified type, and the contracting party undertakes to collect the produce within the agreed period of time, pay the agreed price and provide a specified additional performance if the contract or specific provisions provide for the obligation to provide such performance (article $613 \S 1$ of the Civil Code.)

${ }_{55}$ See e.g. D. Łobos-Kotowska, Współczesne funkcje umowy kontraktacji, in: D. Łobos-Kotowska et al. (eds.), Wspótczesne problemy prawa rolnego i cywilnego. Księga jubileuszowa Profesor Teresy Kurowskiej, Warszawa 2018, p. 299 et seq.; A. Suchoń, Z prawnej problematyki umowy kontraktacji w praktyce, "Przegląd Prawa Rolnego" 2017, No 1, p. 165 et seq.

56 See: L. Russo, Reforma WPR z 2013 r. i stosunki umowne pomiędzy uczestnikami rynku, "Przegląd Prawa Rolnego" 2014, No 2, p. 151 et seq.

${ }^{57}$ See e.g. I. Lipińska, Contractual relations on the EU Agricultural market in the context of food security and production risk, in: I. Härtel. R. Budzinowski (eds.), Food Security, Food Safety, Food Quality, Baden-Baden 2016, p. 187 et seq.; M. Hejbudzki, Umowa dotyczaca dostawy mleka surowego jako instrument prawny systemu organizacji rynku mleka i przetworów mlecznych $w$ Polsce, "Studia Iuridica Agraria" 2017, vol. XV, p. 125 et seq. 
been a complete study on contractual relationships on the agricultural market. ${ }^{58}$ A problem that has been noted and analysed though was that of counteracting unfair market practices. ${ }^{59}$

In turn, direct payments, which are an element of the first pillar of the CAP, have long been the subject of constant interest of agricultural law (already in the pre-accession period). Such issues as the genesis and functions and the legal nature of this instrument for supporting agricultural income were quickly addressed and described. ${ }^{60}$ Over time, with the changes in the CAP introduced in subsequent funding periods, various specific issues of these payments also become the focus of interest of agricultural lawyers. ${ }^{61}$ A commentary to the Act on direct payments facilitated their application in practice. ${ }^{62}$ However, always, also in other studies, the need for equalisation of direct payments remained a constant theme. ${ }^{63}$

The issues concerning food, which is the second element of the aforementioned triad, were not alien to the science of agricultural law well before Poland

${ }^{58}$ An example from the Italian literature may be a monograph by M. Imbrenda, Le relazioni contrattuali nel mercato agroalimentare, Napoli 2016. Also see A. Janarelli, I contratti nel sistema agroalimentare, in: L. Costato, A. Germanò, E. Rook Basile (eds.), Trattato di diritto agrario, vol. 3, Torino 2011, p. 423 et seq.

${ }_{59}$ See e.g. I. Lipińska, Producent rolny wobec nieuczciwych praktyk handlowych-wybrane zagadnienia prawne, "Przegląd Prawa Rolnego" 2017, No 2, p. 61 et seq.; A. Kapała, Przeciwdziałanie nieuczciwym praktykom rynkowym $w$ tańcuchu dostaw żywności w prawie włoskim, "Przegląd Prawa Rolnego" 2017, No 2, p. 133 et seq.

${ }^{60}$ See e.g. E. Tomkiewicz, Geneza i funkcje rolniczych dopłat bezpośrednich w ustawodawstwie wspólnotowym, in: R. Budzinowski (ed.), Problemy prawa rolnego i ochrony środowiska, Poznań 2004, p. 235 et seq.; J. Bieluk, Charakter prawny płatności w systemie wsparcia bezpośredniego, in: B. Jeżyńska (ed.), Obrót gospodarczy w prawie rolnym, Lublin 2009, p. 205 et seq.

${ }_{61}$ M. Król, Nowe rozwiazania prawne $w$ zakresie platności w ramach systemów wsparcia bezpośedniego, "Studia Iuridica Agraria” 2015, vol. XIII, p. 77 et seq.; B. Jeżyńska, Znaczenie i funkcje zasady cross-compliance $w$ systemie rolniczych dopłat bezpośrednich, "Studia Iuridica Lubliniensia" 2010, No 13, p. 35 et seq.; A. Niewiadomski, The Direct Payments in European and Polish Agriculture with Particular Emphasis on the Greening Policy, "Studia Iuridica" 2016, issue 66, p. 287 et seq.; D. Milanowska, Ptatność za zazielenienie w nowym modelu dopłat bezpośrednich, "Studia Iuridica Agraria" 2015, vol. XIII, p. 7 et seq.; A. Niewiadomski, Nowy system płatności bezpośrednich $w$ rolnictwie europejskim i polskim ze szczególnym uwzględnieniem polityki zazielenienia, "Studia Iuridica" 2016, vol. 66, p. 287 et seq.

62 J. Bieluk, D. Łobos-Kotowska, Ustawa o płatnościach bezpośrednich w rolnictwie. Komentarz, Warszawa 2008.

${ }^{63}$ See e.g. S. Balcerak, Nowe oblicze debaty nad wyrównaniem płatności bezpośrednich w prawie wspólnotowym, "Przegląd Prawa Rolnego" 2009, No 1, p. 121 et seq. K. Marciniuk spoke about the need for equalisation of direct payments in his communication "The convergence of direct payments from an Eastern European point of view" delivered during the colloquium "The reform of the CAP" on 20 September 2019 during the $30^{\text {th }}$ European Agricultural Law Congress in Poznań. 
became a member of the EU. ${ }^{64}$ However, the inclusion of Polish agriculture in the CAP mechanisms became an important impulse to study its legal aspects treated as food law or agri-food law. Monographic studies or works that covered these issues in a fairly comprehensive way were published relatively quickly, ${ }^{65}$ and so were studies analysing many specific or detailed issues (such as official food control, sanctions in food law, organic farming quality system, genetically modified food, or novel food. $)^{66}$ The culmination of the research to date has been a piece of work of a treatise character, entitled The system of food law. ${ }^{67}$

It would be difficult to indicate at this point in a relatively detailed way all the issues raised in numerous articles published. They are very numerous and varied in terms of topics. Needless to say that the basic aspects studied concerned food safety and food security, also in the context of genetically modified food, novel food, or nanotechnology, ${ }^{68}$ or direct sales of agricultural products, quality systems, including organic farming products quality schemes, distinguishing local products and the like. ${ }^{69}$ The fact that consideration is being given to relatively new challenges facing agriculture and food economy, such as for

${ }^{64}$ As evidenced by e.g. the monograph by J. Paliwoda, Uwagi o prawie żywnościowym, Warszawa 1997.

${ }^{65}$ A. Oleszko, Prawo żywnościowe wspólnotowego rynku rolnego, Warszawa 2006; M. Korzycka-Iwanow, Prawo żywnościowe. Zarys prawa polskiego i wspólnotowego, Warszawa 2007; M. Korzycka-Iwanow (ed.), Studia z prawa żywnościowego, Warszawa 2006; M. Taczanowski, Prawo żywnościowe, Warszawa 2017.

${ }^{66}$ See e.g. P. Wojciechowski, Wspólnotowy model urzędowej kontroli żywności, Warszawa 2008; idem, Model odpowiedzialności administracyjnej w prawie żywnościowym, Warszawa 2015; I. Wrześniewska-Wal, Żywność genetycznie zmodyfikowana. Aspekty prawne, Warszawa 2008; K. Leśkiewicz, System jakości produktów rolnictwa ekologicznego. Aspekty prawne, Warszawa-Poznań 2011; M. Korzycka, P. Wojciechowski (eds.), Urzędowa kontrola żywności. Teoria i praktyka, Warszawa 2018; Ł.M. Sokołowski, Prawne aspekty wprowadzania...

${ }^{67}$ M. Korzycka, P. Wojciechowski, System prawa żywnościowego, Warszawa 2017. The book also contains extensive reflections on EU food law. See: L. Costato, F. Albisinni (eds.), European and Global Food Law, $2^{\text {nd }}$ edition, Vicenza 2016.

${ }^{68}$ See e.g. K. Leśkiewicz, Bezpieczeństwo żywnościowe i bezpieczeństwo żywności-aspekty prawne, "Przegląd Prawa Rolnego" 2012, No 1, p. 179 et seq.; M. Korzycka, P. Wojciechowski, Regulacja prawna żywności genetycznie zmodyfikowanej w USA i UE w kontekście planowanego Transatlantyckiego Porozumienia Handlowo-Inwestycyjnego (TTIP), "Studia Iuridica Lublinensia” 2017, No 1, p. 465 et seq.; M. Stańko, Konsument w systemie bezpieczeństwa żywności po akcesji Polski do Unii Europejskiej, in: P. Litwiniuk (ed.), Integracja europejska jako determinanta polityki wiejskiej. Aspekty prawne, Warszawa 2017, p. 415 et seq.

${ }^{69}$ A. Kapała, Sprzedaż bezpośrednia produktów rolnych - aspekty prawno-porównawcze, "Przegląd Prawa Rolnego" 2012, No 1, p. 151 et seq.; S. Prutis, Regulacje prawne produkcji ekologicznej w prawie polskim, "Studia Iuridica Agraria" 2013, vol. XI, p. et seq.; A. Kapała, Z prawnej problematyki wyróżniania produktów lokalnych, "Przegląd Prawa Rolnego" 2017, No 2, p. 51 et seq. 
example, prevention of food waste, is much welcome. ${ }^{70}$ What is more, for the purposes of applying the law, there are commentaries to the basic legislative acts published, regarding the issues discussed here. ${ }^{71}$ As can be seen, the science of food law (or agri-food law) is developing very intensively, addressing not only regional but also international aspects. ${ }^{72}$

The environment, apart from agriculture and food, is the third element of the previously mentioned triad, expressing interdependencies and directions of influence. The science of agricultural law has long dealt with certain aspects of environmental protection, predominantly the protection of agricultural land. Including Polish agriculture with the CAP mechanisms has resulted in a significant expansion of the research field and at the same time in the intensification of research. Subsequent changes in this policy have further deepened the environmental dimension of EU agricultural law; the preservation and protection of the environment became a parameter for the evaluation of activities undertaken in agriculture, including the assessment of the CAP instruments used. Although there has not been as yet a monograph authored by Polish agricultural lawyers that would provide a comprehensive analysis of agri-environmental issues ${ }^{73}$ numerous papers and articles of the subject have been published.

The first to mention are publications on more general issues such as greening of the CAP and agricultural law, sustainable development and biodiversity, the role of legal and financial instruments, agri-environment-climate measures or the Nature 2000 sites. $^{74}$ The scientific achievements are much richer when

${ }^{70}$ See e.g. K. Leśkiewicz, Prawne aspekty przeciwdziałania marnowaniu żywności, "Przegląd Prawa Rolnego" 2015, No 2, p. 119 et seq.; Ł.M. Sokołowski, O potrzebie catościowej prawnej regulacji przeciwdziałania marnowaniu żywności, "Przegląd Prawa Rolnego" 2019, No 1, p. 53 et seq. There is a lack of a comprehensive study that might be modelled on the monograph by G. Maccioni, Spreco alimentare. Regole e limiti nella transizione verso modelli agroalimentari sostenibili, Torino 2018.

${ }^{71}$ See e.g. A. Szymecka-Wesołowska (ed.), Bezpieczeństwo żywności i żywienia. Komentarz, Warszawa 2013; K. Leśkiewicz, Ustawa o rolnictwie ekologicznym. Komentarz, Warszawa 2017.

${ }^{72}$ The source of inspiration may be monographs by, among others, M. Alabrese, Il regime della food security nel commercio agricolo internazionale. Dall'Hawana Charter al processo di riforma dell'Accordo agricolo WTO, Torino 2018 and F. Capelli, La tutela dei prodotti agroalimentari di qualità in Italia e in Europa. Un'evoluzione giuridica di successo, Napoli 2018.

${ }^{73}$ Not of such a character is the monograph by A. Niewiadomski, Publicznoprawny i prywatnoprawny konflikt interesów na przykladzie Europejskiej Sieci Ekologicznej Natura 2000, Warszawa 2017.

${ }^{74}$ See e.g. B. Jankowski, Oddziatywanie Wspólnej Polityki Rolnej na ochronę środowiska, "Studia Iuridica Agraria" 2012, vol. X, p. 513 et seq.; S. Prutis, Ochrona środowiska za pomoca instrumentów prawno-finansowych Wspólnej Polityki Rolnej, "Studia Iuridica Agraria" 2015, 
it comes to various detailed aspects of the agri-environmental issues discussed here. These include, for example, articles on the protection of particular elements of the environment implemented in connection with the agricultural activity conducted, the environmental dimension of various CAP instruments, climate protection or animal protection. ${ }^{75}$ As can be seen, the issues discussed in the Polish literature do not differ from the topics discussed in foreign publications. ${ }^{76}$

The achievements of Polish agricultural law concerning rural development are also worth noting. While they have not been fully compiled in the form of a monograph, they are more widely discussed in the nationwide handbook, ${ }^{77}$ and the results of studies on two important issues (the aid contract and the rural development program) have been published in the form of books. ${ }^{78}$ However, numerous articles address problems of a more general nature, such as the con-

vol XII, p. 39 et seq.; A. Niewiadomski, Prośrodowiskowe determinanty polskiej i europejskiej polityki rolnej, "Studia Iuridica Lublinensia" 2017, No 1, p. 271 et seq.; M. Król, Ocena modelu prawnej ochrony środowiska we Wspólnej Polityce Rolnej, "Studia Iuridica Lublinensia" 2017, No 1, p. 227 and P. Gała, Ochrona różnorodności biologicznej jako determinanta Wspólnej Polityki Rolnej, "Studia Iuridica Lublinensia" 2017, No 1 p. 193 et seq.; E. Nawrotek, Działanie rolno-środowiskowo-klimatyczne jako instrument ochrony środowiska w rolnictwie, in: B. Jeżyńska, E. Kruk (eds.), Prawne instrumenty ochrony środowiska, Lublin 2016, p. 353 et seq.; B. Jeżyńska, R. Pastuszko, Ochrona bioróżnorodności przed uwalnianymi do środowiska obcymi gatunkami inwazyjnymi. Zagadnienia prawne, in: ibidem, p. 255 et seq.; A. Niewiadomski, Prawne instrumenty ksztaltowania obszarów Natura 2000 w Polsce, in: ibidem, p. 327 et seq.

${ }^{75}$ See e.g. B. Kuraś, Zasada ,zanieczyszczający płaci” a odpowiedzialność za zanieczyszczenie gleby spowodowane działalnościa rolnicza (zagadnienia wybrane), "Przegląd Prawa Rolnego" 2012, No 1, p. 215 et seq.; M. Król, Środowiskowy wymiar płatności w ramach systemów wsparcia bezpośredniego - zagadnienia prawne, in: B. Jeżyńska, E. Kruk (eds.), Prawne instrumenty..., p. 295 et seq.; J. Goździewicz-Biechońska, Przeciwdziałanie degradacji ziemi i gleby jako globalne wyzwanie dla prawa, "Przegląd Prawa Rolnego" 2018, No 1, p. 41 et seq.; E. Jachnik, Prawne aspekty ochrony zapachowej jakości powietrza, "Przegląd Prawa Rolnego" 2017, No 1, p. 149 et seq.; I. Lipińska, Z prawnej problematyki dobrostanu zwierząt gospodarskich, "Przegląd Prawa Rolnego" 2015, No 1, p. 63 et seq.; P. Gała, Problematyka bioróżnorodności w nowym PROW na lata 2014-2020, "Studia Iuridica Agraria" 2015, vol. XIII, p. 165 et seq.

${ }^{76}$ See e.g. V. Nies, Aktuelle Entwicklungen im Agrarumweltrecht, "Agrar- und Umweltrecht” 2013, No 2, p. 47 et seq.; C. Blumann, L'écologisation de la politique agricole commune, "Revue de Droit Rural" 2014, No 425, p. 24 et seq.; J. Foyer, Le droit rural confronté à la protection des sols, "Revue de Droits Rural" 2017, No 449, p. 1; idem, Retour sur les liens du droit rural et de l'agriculture durable, "Revue de Droit Rural" 2017, No 452, p. 1 et seq.; A. Scheidler, Naturschutzrechtliche Eingrriffsregelung und Landwirtschaft, "Agrar- und Umweltrecht" 2019, No 3, p. 88 et seq.

${ }_{77}$ This is a chapter of the nationwide handbook by P. Czechowski (ed.), Prawo rolne...

${ }^{78}$ D. Łobos-Kotowska, Umowa przyznawania pomocy z Europejskiego Funduszu Rolnego na rzecz Rozwoju Obszarów Wiejskich, Warszawa 2013; P. Litwiniuk, Program Rozwoju Obszarów Wiejskich jako dokument programowy i źródło prawa rolnego, Warszawa 2018. 
cept of rural areas, the selection of support instruments for these areas, their functions, the characteristics of support beneficiaries, or the evaluation of programmes in subsequent periods of financing. ${ }^{79}$ Other articles deal with specific problems of support for rural development, including, for example, selected instruments for supporting rural development, aid contracts, liability of beneficiaries and sanctions, or the procedure for granting support. ${ }^{80}$ The research problems presented herein in the field of rural development are also within the scope of interest of the Western European agricultural lawyers. ${ }^{81}$

The inclusion of Polish agriculture in the CAP mechanisms brought effects resulting in a significant internationalisation of research activity. The articles by Polish researchers representing almost all scientific centres are published in the "CEDR Journal of Rural Law" issued by the European Committee of Agricultural Law, as well as in other scientific journals mentioned herein. Foreign authors

79 See e.g. M. Krzysztofik, Problematyka prawna pojęcia obszaru wiejskiego, "Studia Iuridica Lublinensia" 2017, No 1, p. 299 et seq.; S. Prutis, Dobór instrumentów prawnych stużacych wsparciu rozwoju obszarów wiejskich, "Studia Iuridica Agraria" 2009, vol. VII, p. 192 et seq.; J. Mikołajczyk, Współczesne funkcje obszarów wiejskich na tle koncepcji multifunkcjonalnego rolnictwa, "Studia Iuridica Agraria” 2012, vol. X, p. 367 et seq.; P. Blajer, Beneficjenci „Programu Rozwoju Obszarów Wiejskich," "Przegląd Prawa Rolnego” 2010, No 1, p. 13 et seq.; E. Tomkiewicz, Polityka rozwoju obszarów wiejskich na lata 2007-2013 (perspektywy na tle dotychczasowej ewolucji ustawodawstwa), "Studia Iuridica Agraria" 2007, vol. VI, p. 23 et seq.; P. Będzmirowska, Program Rozwoju Obszarów Wiejskich na lata 2014-2020, "Studia Iuridica Agraria” 2013, vol. XI, p. 85 et seq.

${ }^{80}$ See e.g. J. Zięba, Renty strukturalne w ustawodawstwie rolnym, Warszawa 2013; P. Blajer, Zmiana generacji w gospodarstwach rolnych $w$ Polsce $w$ świetle polityki rozwoju obszarów wiejskich (aspekty prawne), "Przegląd Prawa Rolnego" 2010, No 2, p. 161 et seq.; B. Jeżyńska, Prakseologiczne instrumenty wsparcia zrównoważonego rozwoju obszarów wiejskich, "Studia Iuridica Agraria" 2012, vol. X, p. 251 et seq.; T. Kurowska, Założenia konstrukcyjne umowy przyznania płatności z Europejskiego Funduszu Rolnego na rzecz Rozwoju Obszarów Wiejskich, "Studia Iuridica Agraria" 2009, vol. VII, p. 163 et seq.; D. Łobos-Kotowska, Umowa przyznania pomocy z Europejskiego Funduszu Rolnego na rzecz Rozwoju Obszarów Wiejskich a inne podobne umowy, "Studia Iuridica Agraria" 2012, vol. X, p. 265 et seq.; P. Wojciechowski, Odpowiedzialność karna i administracyjna beneficjentów pomocy z Programu Rozwoju Obszarów Wiejskich, "Studia Iuridica Agraria" 2012, vol. X, p. 281 et seq.; E. Kremer, Wybrane zagadnienia $z$ problematyki rozwoju obszarów wiejskich, płatności bezpośrednich $w$ orzecznictwie sądów administracyjnych, "Studia Iuridica Agraria" 2009, vol. VII, p. 142 et seq.

81 J. Martínez, Pojęcie ,, obszar wiejski” jako odpowiedź na wielofunkcyjność przyszłej dziatalności rolniczej, "Przegląd Prawa Rolnego" 2010, No 2, p. 47 et seq.; R. Norer, Skizzen aus der agrarrechtlichen Zukunft: ein Recht des ländlichen Raums? (1), "Agrar- und Umweltrecht" 2008, issue 5, p. 157 et seq.; P.A. Llombart, La normativa comunitaria de desarrollo rural frente a los nuevos retos y prioridades de la Unión Europea, "Revista de Derecho Agrario y Alimentario" 2010, No 57, p. 7 et seq.; L.A. Bourges, Agricoltura y urbe: ventajas y desafios frente a la necesidad de un desarrollo integral, "Revista de Derecho Agrario y Alimentario" 2015, No 66, p. 51 et seq. 
are increasingly present in domestic publications of a monographic nature, ${ }^{82}$ and in journals. ${ }^{83}$ The scientific cooperation with the former Istituto di Diritto Agrario Internazionale e Comparato in Forence, and the Institut für Landwirtschaftsrecht of the University in Göttingen has a particularly long tradition ${ }^{84}$ Currently, academic contacts are maintained with many research centres abroad.

Polish agricultural lawyers participate in scientific conferences held abroad, including congresses organised by the Unione Mondiale degli Agraristi Universitari and the Comité Européen de Droit Rural. They are also organisers or co-organisers of such events. In 2005, the first Italian-Polish conference was held at the University of Macerata under the significant title "Politica agricola comune e allargamento a Est. Un confronto italo-polacco." The subsequent three conferences were also organised by the Polish side (the University of Poznań) and one by the Italian side. There have also been two joint conferences held, organised in cooperation with Spanish scholarship and four with German scholarship. ${ }^{85}$

The activity of Polish agricultural lawyers has found recognition in international circles. And for example, the organisation of the $15^{\text {th }}$ World Congress on Agricultural Law and the $30^{\text {th }}$ European Congress and Colloquium on Agricultural Law was entrusted with the Polish organisers. The World Congress was held in Poznań in 2018 and its tangible result is the congress book entitled "The $15^{\text {th }}$ World Congress of Agricultural Law. Contemporary challenges of Agricultural Law: among Globalisation, Regionalisation and Locality." The European Congress, also held in Poznań in 2019, and its organisation was very highly rated by the CEDR authorities.

4. The considerations carried out confirm the thesis formulated at the beginning of this article about a significant reduction of the distance between the Polish science of agricultural law and Western European science. This statement refers to all analysed spheres of agricultural legislation. The issues undertaken by Polish agricultural lawyers fall within the scope of interest of their Western European counterparts. The increase in research intensity is visible, as well as the resolution of original and innovative problems. It may therefore

${ }^{82}$ See e.g. P. Litwiniuk (ed.), Kwestia agrarna. Zagadnienia prawne i ekonomiczne, Warszawa 2016.

83 Primarily in the journal "Przegląd Prawa Rolnego."

${ }^{84}$ As written by A. Germanò, L'Istituto di Diritto Agrario Internazionale e Comparato: la storia, Napoli 2017 and W. Winkler, 50 Jahre Institut für Landwirtschaftsrecht der Universität Göttingen, in: J. Martínez (ed.), Die Gemeinsame Agrarpolitik vor neuen Herausforderungen, Baden-Baden 2012, p. 143 et seq.

${ }^{85}$ The outcome of two conferences organised together with the Viadrina University in Frankfurt Oder is a book by I. Härtel, R. Budzinowski (eds.), Food Security, Food Safety... 
be said that Polish agricultural lawyers are increasingly becoming partners in research conducted by foreign scholars, and the use of their research and organisational potential may also be useful on an international forum.

\title{
THE SCIENCE OF AGRICULTURAL LAW IN POLAND. REFLECTIONS AGAINST THE BACKGROUND OF WESTERN EUROPEAN SCIENCE
}

\author{
Summary
}

The fifteenth anniversary of the inclusion of Polish agriculture in the CAP mechanisms prompts one to make summaries and comparisons and formulate evaluations of the development of the science of agricultural law in the European context. The deliberations presented in the article are an attempt to formulate a few valid reflections, focusing on the comparison of the EU agricultural acquis, the general (theoretical) agricultural (national) law issues, traditional agricultural law issues, agri-food and agri-environmental law and rural development.

As it is demonstrated in the article, the distance between the Polish science of agricultural law and Western European science has significantly narrowed. The issues undertaken by Polish agricultural lawyers fall within the scope of interest of their Western European counterparts. It may therefore be said that Polish agricultural lawyers are increasingly frequently becoming partners in research conducted by foreign scholars, and the use of their research and organisational potential may also be useful on an international forum.

\section{LA SCIENZA DEL DIRITTO AGRARIO IN POLONIA NEL QUADRO DELLA SCIENZA DELL'EUROPA OCCIDENTALE}

\section{Riassunto}

Il quindicesimo anniversario dall'inclusione dell'agricoltura polacca nei meccanismi della PAC incoraggia a sintetizzare e valutare lo sviluppo della scienza del diritto agrario nel contesto europeo. Nelle considerazioni svolte si tenta quindi di formulare alcune fondamentali riflessioni, nonché mettere a confronto i contributi nei seguenti campi: il diritto agrario dell'UE, le questioni generali (teoriche) del diritto agrario (nazionale), le questioni tradizionali del diritto agrario, diritto agroalimentare e agroambientale, e quello riguardante lo sviluppo rurale.

In conclusione, l'autore afferma che le distanze tra la scienza polacca del diritto agrario e quella dell'Europa occidentale si sono notevolmente ridotte. I problemi sollevati dagli agraristi polacchi si collocano nell'area di interesse degli agraristi dell'Europa occidentale. Pertanto, si può affermare che i primi stanno, sempre di più, diventando partner nelle ricerche condotte dai secondi, inoltre le loro capacità di ricerca, come anche quelle organizzative, possono tornare utili persino in un forum internazionale. 